\title{
Influence of gender on SME performance in emerging economies
}

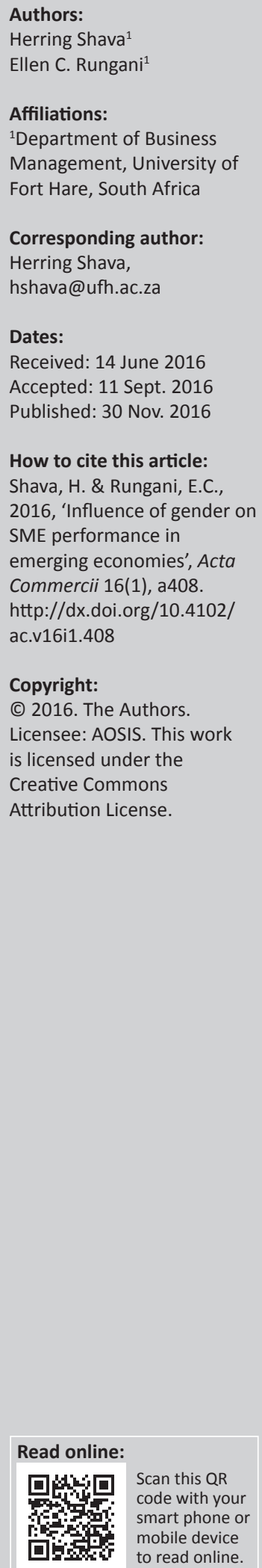

Research purpose: The aim of this article was to establish whether or not performance between male-owned and female-owned small and medium-sized entities (SMEs) differs significantly and to assess the extent to which the gender gap in SME performance (if any) could be allocated to gender differences in levels of business-related experience.

Motivation for the study: The influence of gender on SME performance is well documented from an international perspective. However, what lacks in extant literature is the understanding of whether the performance gap between male and female entity owners with similar businessrelated experience exists or not. This study investigated gender influence through data collected from both male and female entity owners.

Research design, approach and method: The study was descriptive by design. Primary data were collected through self-administered questionnaires. Data analysis was undertaken through $t$-test and chi-square analysis.

Main findings: The findings confirm that male- and female-owned SMEs perform at similar levels, given that such owners possess high business-related experience. Therefore, gender gap in firm performance does not exist among male and female entrepreneurs who fall either in low or high business-related experience categories.

Contribution/value-add: The value of this research lies in the findings contrary to extant literature; that gender plays no role in the performance of SMEs. However, the level of business-related experience the owner holds, regardless of gender, influences the entity's performance.

Conclusion: Contrary to evidence provided in literature, the study concludes that focusing on the impact of gender on entrepreneurship with the aim of comparing business outcomes of male- and female-owned entities, while ignoring the role of key variables such as businessrelated experience, may yield misleading results.

\section{Introduction}

The severity of specific problems faced by small and medium-sized entities (SMEs) differs, owing to the business sector, SME owner's/manager's gender and experience, size of the business, legal structure as well as age of the firm (Fatoki \& Asah 2011; Omiunu 2014). Without controlling for any variables, evidence from Cameroon, an emerging economy, reveals that gender is not associated with business outcomes (Akinboade 2015). Extant literature from established economies shows that performance of SMEs is strongly linked to prior business experience of the owner/ manager (Delmar \& Wiklund 2008; Dyke, Fischer \& Reuber 1992; Richbell, Watts \& Wardle 2006). Soriano and Castrogiovanni (2012) and Popescu, Deaconu and Popescu (2014) pointed out that most firms underperform because of a lack of managerial skills and experience. In small firms, the owner often assumes the role of a manager (Popescu et al. 2014). Owing to this condition, the performance of the entity relies heavily on the experience of the owner/manager. This implies that business-related experience plays a significant role in a firm's performance. In addition, literature suggests that business-related experience varies between male and female firm owners (Fischer, Reuber \& Dyke 1993; Gottschalk \& Niefert 2012). In light of this debate, this study sought to establish whether or not performance between male-owned and female-owned SMEs differs significantly, and to assess the extent to which the gender gap in SME performance (if any) could be allocated to gender differences in levels of business-related experience.

Evidence provided by Fapohunda (2013) from Nigeria, an emerging economy, highlights that business-related experience of SME owners is mixed, thereby leading to mixed business outcomes. Gottschalk and Niefert (2012) as well as Eikhof, Summers and Carter (2013) pointed out that 
female-owned businesses are not only fewer in number but are also characterised by lower outcomes compared with their male-owned counterparts. This is in contrast to earlier evidence, also from Nigeria, provided by Mba (2006). Mba (2006) revealed that women entrepreneurs possess less valuable, managerial and self-employment experience; thus suggesting that women-owned firms are likely to underperform owing to lack of business-related experience. Conversely, Amobi (2006) provided evidence that female entrepreneurs have similar, and sometimes more, businessrelated experience than male entrepreneurs.

The mentioned issues imply that gender plays a pivotal role in disclosure of differences, thereby leading to an observed performance gap. However, there is no consensus among researchers on this topic, and research is necessary to help our understanding. There is little research from a South African perspective focusing on gender differences and SME performance. Therefore, studies carried out in developed countries such as Germany (Gottschalk \& Niefert 2012) and the USA (Fairlie \& Robb 2009) are not fully adequate to substantiate theories related to gender differences. After a thorough review of literature, it became evident that literature with regard to gender differences and SME performance, particularly from emerging economies, is limited when compared with evidence from developed countries. However, Terjesen and Hessels (2016) argued that it is important to reveal the diverse nature of entrepreneurship across countries, specifically its role in explaining business outcomes at micro- and macrolevels. In an attempt to contribute to entrepreneurship literature, this study adopts a different dimension and focuses on gender differences and SME performance from an emerging economy's perspective.

\section{Research objectives}

The article investigated whether performance differs between male-owned and female-owned South African SMEs. Firm performance can be assessed making use of growth and profitability measures. Carton and Hofer (2006) argued that growth is an essential indicator of firm performance and success. To measure SME performance, we adopted growth indicators, namely growth in sales, growth in market share, growth in employees, growth in profitability, increase in profit margins and the ability to fund expansion activities from profit. These indicators were preferred as they highlight the effectiveness of a firm in expanding in existing markets or opening new markets. Financial performance is often measured through profit measures such as return on assets and return on sales. Profit measures in their essence shed light on the firm's operational efficiency. The discussion to follow provides theoretical background to the study. After the theoretical background, we then describe how femaleowned enterprises perform poorly when compared with male-owned enterprises. According to Klapper and Parker (2011), this claim is well supported in literature. This led us to critically examine the credibility of the notion that when an entity is male-owned, it therefore follows that it will outperform a female-owned entity. To undertake this task, we controlled business-related experience between genders. Thus, we attempted to establish the degree to which the gender gap in SME performance could be allocated to gender differences in levels of business-related experience. Although literature is reviewed from both developed and developing nations, we seek to contribute to this debate through evidence from an emerging economy's perspective.

\section{Theoretical background}

The social feminist (hereafter, SF) theory outlines that women differ inherently, because of differences derived from early socialisation (Calas \& Smircich 1989). Compared with men, women thus inherently have different attitudes towards risk and growth, and as a result they pursue different goals (Verheul, Thurik \& Grilo 2008). Due to their different attitudes towards risk and growth, women, therefore, adopt a different approach to business activities, thus resulting in small business entity size and lower expansion rates (Gottschalk \& Niefert 2012). As pointed out by Fischer, Reuber and Dyke (1993), the SF theory holds that there are differences between males' and females' experiences from the earliest moments of life. In the course of life, these differences result in both men and women viewing the world differently. Calas and Smircich (1989) indicated that the SF theory argues that female experiences present an equally valid basis for the development of knowledge and organising the society. Compared to the liberal feminist theory's view, males and females are not considered essentially similar by fundamental nature. Thus, males and females are able to share experiences which are assumed to help define a group-based rationality or mode of comprehension. It is, however, argued that neither the male nor the female mode of perception is regarded as innately superior or more functional to the benefit of society (Gottschalk \& Niefert 2012).

\section{Literature review}

The literature review section is organised as follows: the influence of gender on SME performance, gender differences in SME performance and contributing factors to the gender gap in SME performance.

\section{Influence of gender on SME performance}

To illustrate the influence of gender on SME performance, research highlights several gender-related factors that either positively or negatively affect business performance. Such issues vary and include cultural factors, hours worked by owner, domestic and child care responsibilities for both men and women and tasks performed in business by both sexes, among others.

\section{Cultural presuppositions by gender related to business performance}

Female-owned businesses, in absolute terms, are less than those owned by men (Eikhof et al. 2013; Gottschalk \& Niefert 2012). It has also come to light that women's overall experience, skills and knowledge of venturing into business activities are below average (Naudé 2013). On the other hand, 
traditional expectations with regard to the male gender in societal settings have not shifted significantly. In other words, societies still consider men as breadwinners, whereas women are expected to fulfil household duties and, more importantly, to care for the family (Chinomona \& Maziriri 2015). It is, therefore, appropriate to indicate that female SME owners experience a 'dual burden' daily (Singh 2012). To that effect, female SME owners operating their own business enterprises are more likely to have lower motivation to achieve high performance, compared with their male counterparts, as their time has to be divided between work and home (Hundley 2001). This has a negative impact on women's entrepreneurial efforts, and more importantly, the ability to gain business-related experience, which is crucial for better firm performance (Klapper \& Parker 2011).

\section{Hours worked by owners and business performance}

In their study, Elizabeth and Baines (1998) found that $47 \%$ of business owners surveyed, reported working at least 48 hours in a normal week. However, $69 \%$ of the respondents revealed working at least 48 hours in a busy week. Furthermore, the male mean number of normal working hours for sole men-owned businesses was found to be 49 hours per week, compared with 43 hours for sole femaleowned enterprises. The sharp difference between the two is most likely a factor of the respective obligations of males and females related to family care and domestic work (Hundley 2001). As indicated earlier, women in business face the 'dual burden' and therefore in some instances they face the inevitable, which includes trading off potential income earning time for time devoted to household tasks. Research concurs with the above assertion and points out that when it comes to time and energy, female small business owners, compared with their male counterparts, are more strained by domestic responsibilities and fewer working hours (Fairlie \& Robb 2009; Gottschalk \& Niefert 2012). However, Eikhof et al. (2013) found that women who operate micro-enterprises from their backyard were also working long hours just like men. This also suggests that the variance in working hours between men and women is a result of sector, entity type and business location.

\section{Domestic tasks and child care responsibilities and business performance}

Research shows that married enterprise owners have the highest proportion of dependent children (Eikhof 2012; Elizabeth \& Baines 1998). Research further indicates that women, not men, bear the main responsibility of caring for the children (Eikhof et al. 2013). This suggests that femaleowned SMEs are less likely to perform at the same level as male-owned SMEs, since women SME owners have to divide their productive time in a way that accommodates diverse tasks such as domestic work and child care responsibilities in addition to their business ventures (Hundley 2001).

\section{Tasks performed in business by males and females}

When married couples participate in business activities together, their roles are more likely to follow traditional gender- related roles or patterns. Therefore, an insignificant number of married SME owners share professional and management tasks. A South African study by Billson (2011) reported that women are responsible for the downfall and poor growth of their firms as they are not as proactive and adventurous as men. Thus, women are more active in secretarial activities and invisible in decision-making (Vadnjal \& Zupan 2009). Boden (1996) argued that administrative jobs reward women with work experience that poorly matches entrepreneurship demands in case they switch careers in the future.

\section{Input into business by women and men and business performance}

Powell, Kimberly and Eddleston (2008) argued that owner inputs acquired prior to firm ownership have a significant influence on the performance of the firm. Menzies, Diochon and Gasse (2004) supported this notion and pointed out that literature reveals that inputs of male and female SME owners play a major role when accounting for growth limitations and underperformance of female-owned SMEs. In emerging economies, inputs of males and females vary, ranging from human capital to financial capital resources (Fatoki 2011). According to Elizabeth and Baines (1998), married women who are in business together with their husbands tend to perform business activities of which they normally have limited experience, and therefore prior training is crucial in executing such tasks. On the contrary, male business owners often venture into business sectors of which they have previously gained the required skills and related experience (Fairlie \& Robb 2009).

It should, however, be noted that regardless of whether married men or women participate together either as employees, or unpaid helpers, gender divisions of labour are generally influenced by tradition or culture (Botha 2009; Goffee \& Scase 1985). However, there are various benefits of seeking family support in both men- and women-owned businesses. For example, it is clear that during unfavourable economic conditions, family support could enhance the possibility of the survival. Furthermore, male and female SME owners who have growth as their main goal have a choice to rely or not to rely on their spouse or other family members who are likely to work tirelessly in order to create and maintain wider networks, which could generate information, ideas and skills.

\section{Gender differences in SME performance}

Literature from established economies provides a clear picture of how male- and female-owned firms differ in performance-related issues - firm closure rates, level of sales, profits and employment creation (Kalleberg \& Leicht 1991; Robb 2002; Robb \& Wolken 2002; Rosa, Carter \& Hamilton 1996). What is common in these studies is that female-owned firms were found more likely to cease business operations than male-owned firms. These findings suggest that femaleowned enterprises have poor levels of profits and sales. In addition, they offer few employment opportunities to the general society. 
Farlie and Robb (2009) analysed data gathered by the Characteristics of Business Ownership between the years 1992 and 1996 for small enterprises in the USA. Fairlie and Robb (2009) compared profits, average employment, closure rates and average sales between female- and male-owned small enterprises. Their findings revealed interesting differences related to gender on different areas of business performance indicators mentioned earlier. First, femaleowned entities compared with $36.4 \%$ of male-owned entities reported profits of at least $\$ 10000$ per annum. Second, female-owned business entities also conducted business activities for a shorter period compared with male-owned business entities. Thus, the average probability of enterprise closure for female-owned business entities was $24.4 \%$, whereas that of their male counterparts was $21.6 \%$. Third, male-owned business entities were found to be substantially superior to female-owned business entities on average sales performance. The mean score for sales was $10.36 \%$ for menowned entities, compared with $9.57 \%$ for women-owned entities. Fourth, male-owned business entities created more job opportunities $(23.2 \%)$ than female-owned business entities (16.4\%).

Significant research endeavours such as those of Fairlie and Robb (2009), Loscocco et al. (1991), Hundley (2001), Coleman (2002), Watson (2002) and Gatewood et al. (2009) came to the same conclusion. These studies focused on sales, employment creation and profits. Their main findings were that femaleowned firms performed poorly in all three performance indicators investigated when compared with male-owned firms. Srinivisan, Woo and Cooper (1994) assessed the impact of gender on firm performance. They relied on data compiled by the National Federation of Independent Business, a US organisation. The probability of firm closure was found to be high for female-owned firms, largely indicating that they were underperforming when compared with male-owned firms. Robb (2000) found that around 25\% of female-owned enterprises had the capacity to hire formal labour. In the same study, the survival rate for male-owned firms was reported to be significantly higher than that of female-owned firms. Boden and Nucci (2000), relying on the 'CBO data', concurred with the findings of Robb (2000) and stated that women-owned firms were less likely to survive than maleowned firms.

Robb (2008) further agreed with other empirical studies mentioned above and relied heavily on 'Kauffman Firm Survey Data' collected from newly established businesses. Robb reported the presence of the gender gap in a firm's performance, which is evident in low turnover, poor earnings, average employment, and more importantly, in survival rates statistics. Empirical evidence available and reviewed suggests that there is a significant difference between gender and firm performance. Consequently, the researchers of this study propose the following hypothesis:

H1: No significant difference exists in performance of male- and female-owned SMEs.
When empirical evidence reviewed is taken into consideration, possible contributing factors to a gender gap in SME performance should receive attention.

\section{Contributing factors to gender gap in SME performance}

The experience of an individual is significantly related to their performance, especially in 'areas of managerial endeavour' (Dyke et al. 1992). In Shava and Rungani (2014), it was highlighted that experience is a variable of human capital. This article broadens the concept of experience. The discussion to follow reviews literature on managerial, industry and prior business ownership experience, conceptualised as business-related experience (Shava \& Rungani 2014). In this discussion, the concept of businessrelated experience is linked to gender and firm performance. The aim of this section is to discuss in detail the gender gap in business-related experience as a contributing factor to the gender gap in firm performance.

\section{Gender, prior business ownership experience and SME performance}

According to Headd (2003), having prior business ownership experience is expected to be positively correlated with performance of a firm. This is likely to be the case as lessons learnt often translate into competent decision-making. However, Robb and Watson (2012) noted that research by Cooper, Gimeno-Gascon and Woo (1994) as well as by Fairlie and Robb (2009) found that women are more likely to possess low levels of prior business ownership experience compared with men. Empirical evidence suggests that human capital variables could, conceivably, affect firm performance (Fatoki 2011; Robb \& Watson 2012). Robb and Watson (2012), however, suggested that human capital variables and other demographic variables should be measured at the same level (controlled) between genders, when assessing entrepreneurial outcomes, for example firm performance. In their study, they report the absence of a gender gap in firm performance after controlling for industry, prior business ownership experience and hours worked.

\section{Gender, managerial experience and SME performance}

Amin and Kushnir (2012) provided evidence from 71 emerging economies by pointing out that managerial experience is quite vital to entrepreneurs, for it can shed light on how to implement and prioritise policies aimed at attaining positive outcomes for a business entity. In their findings, Amin and Kushnir (2012) reported that in 13 out of 71 emerging economies, women were found to possess high managerial experience compared with men. A study conducted by Berger, Kirk and Schaeck (2012), covering German banks, found that teams with more female executives tended to take more risky decisions that were potentially a threat to the firm's future existence. The empirical study further suggests that this finding is influenced by the fact that female executives have less managerial experience than male executives. 


\section{Gender, industry experience and SME performance}

Dyke et al. (1992) found that an owner's previous experience in the industry in which the current firm operates is significantly and positively related to performance. Bosma et al. (2004) investigated the relationship between industry experience and firm performance. Survival, profitability and growth were the performance indicators utilised in that study. The results revealed that industry experience substantially improved firm performance. Keeley and Roure (1990) examined the effect of industry experience on a technology-based firm, and Van De Ven, Hudson and Schroeder (1984) examined the effect of industry experience on an educational software firm. The above studies argued that there is no significant relationship between industry experience and firm performance. However, commenting on the disparities in prior work experiences, Fairlie and Robb (2009) pointed out that the effects of this type of prior work experience are significant and may thus explain part of the gender gap in business performance. De Tienne and Chandler (2007), in their study, revealed how industry experience affected opportunity identification in male and female entrepreneurs. They revealed that for females, the number of previous jobs and industry positively predicted the number of opportunities identified and accounted for $20 \%$ of the variance compared with $5 \%$ in males. The findings of De Tienne and Chandler suggest that the higher the levels of male industry experience, the higher the entrepreneurial outcomes. A significant number of empirical studies reviewed in this section suggests that female SME owners have low levels of business-related experience compared with male SME owners. Given this background, we therefore propose the hypotheses:

H2: No significant association can be found between gender and firm performance among SME owners with high business-related experience.

H3: No significant association can be found between gender and firm performance among SME owners with low business-related experience.

\section{Methodology}

The positivist approach was adopted in undertaking this article. Positivism, as a research paradigm, is objective and independent of the researcher's influence (Myers 2009). In positivism, researchers take note of the view that only logical reasoning is allowed to reinforce the assumptions guiding the study. This article is descriptive by design. Zikmund and Babin (2009) pointed out that in undertaking descriptive research, the researcher relies on some previous understanding of the problem at hand. However, conclusive evidence in the form of primary data is required to answer the research problem and to determine the appropriate course of action (Wiid \& Diggines 2015). Hence, to gather primary data, a quota sample of 109 SMEs based in King William's Town in the Eastern Cape Province, South Africa, was derived. Data were collected from SME owners through a survey.
Due to low respondent rates associated with SME owners, 120 self-administered questionnaires were issued. To arrive at conclusions, recommendations and findings, this quantitative study relied on a $61 \%$ respondent rate.

The self-administered questionnaires were initially pretested on 20 SME owners who were also included in the study. Questionnaire pretesting through a pilot study of 20 respondents was undertaken to serve two crucial purposes, as pointed out by Schwab (2013). First, it was carried out to evaluate whether the targeted respondents were able to interpret and understand each item of the questionnaire correctly. This evaluation helped the researchers to identify errors of assumption about participants' frames of reference and items that were difficult to understand. This led to changes in the design of the research questionnaire, which may have resulted in an increased response rate, reduction of missing data and obtaining of more valid responses to the final questionnaire. The second purpose for carrying out the pilot study was to assess whether scores behaved as per the researchers' expectations. The researchers, at this phase, determined whether the generated average scores were reasonable and that the score items were varying as expected. In addition, the Cronbach's alpha was used to test for reliability of the study. The alpha coefficient value for the performance measurement scale (growth in sales, growth in market share, growth in employees, growth in profitability, increase in profit margin on sales and the SMEs' ability to fund growth from profits) was 0.9, suggesting that the study instrument was reliable. The stated performance measures were adopted from Fatoki (2012) and were measured on a five-point Likert scale. Business-related experience measures were adopted from Cliff (1998). Participants were asked whether they had, in the past, owned a business venture, managed a business venture or worked in an industry similar to the one in which they had a business. These were dichotomous questions which were later summed to derive a business-related experience score for each participant.

In data analysis, the $t$-test was used to determine whether a significant difference exists between gender and firm performance. Furthermore, a chi-square test was used to formally examine the study's control variable (business-related experience) in $\mathrm{H} 2$ and $\mathrm{H} 3$. The chi-square test allows the formal examination of the control variable, given/assuming that the control variable (business-related experience) is measured.

\section{Reporting and discussion of the results}

The results of the study were first undertaken through the independent samples $t$-test where we sought to investigate whether being male or female had an influence in business performance. Later, we incorporated the chi-square test where we controlled for level of business-related experience between genders to critically examine whether there is an association between gender and performance. An 
independent samples $t$-test was conducted to compare firm performance mean scores for male and female entrepreneurs. The results from the independent samples $t$-test carried out to compare performance mean scores for males and females reveal that there is a statistically signicant difference in mean scores for males $(M=3.15, \mathrm{SD}=1.19)$ and females $(M=2.31$, $\mathrm{SD}=1.13, t(68)=3.06 ; p=0.003$, two-tailed $)$. The magnitude of the differences in the means was above moderate to large (eta squared $=0.12$ ). The $t$-test results suggest that gender has an influence on firm performance. In other words, the independent samples $t$-test results reveal that male-owned SMEs outperform female-owned SMEs. Relying on the independent samples t-test, the null hypothesis H1 is therefore rejected. As pointed out by Klapper and Parker (2011), this finding is well supported in literature, and our findings are consistent with the results obtained by Robb (2008) as well as Fairlie and Robb (2009) who indicated that male-owned firms outperform female-owned business entities. The above-mentioned studies conclude that female-owned businesses are more likely to close operations, are less likely to have profits and are less likely to hire employees than male-owned business entities. This finding, therefore, confirms the existence of a gender gap with regard to SME performance. Conversely, before controlling for businessrelated experience between genders, the study's findings dispute the findings of Akinboade (2015) who reported that there is no association between gender and firm performance.

Given this background, we then factored in the chi-square test which allowed for the controlling of business-related experience between genders. The thinking here was that the mere fact that an SME is male owned and will therefore realise superior performance compared with a female-owned SME inadequately answers the debate and could be misleading. Resultantly, we grouped the male and female SME owners into high and low business-related experience categories. This exercise sought to confirm whether the gender gap still existed between the two categories. A cross tabulation and chi-square test were performed. The results appear in partial tables outlined in the contingency table and the chi-square test, as shown in Tables 1 and 2. The descriptive statistics in Table 1 are discussed first, and thereafter Table 2, which focuses on the chi-square test, is discussed.

TABLE 1: Experience, SME performance and gender cross tabulation.

\begin{tabular}{|c|c|c|c|c|c|c|c|}
\hline \multirow[t]{3}{*}{ Experience } & \multirow[t]{3}{*}{ Gender } & \multicolumn{4}{|c|}{ SME performance } & \multicolumn{2}{|c|}{ Total } \\
\hline & & \multicolumn{2}{|c|}{ High firm performance } & \multicolumn{2}{|c|}{ Low firm performance } & \multirow[b]{2}{*}{ Count } & \multirow[b]{2}{*}{$\%$ within gender } \\
\hline & & Count & $\%$ within gender & Count & $\%$ within gender & & \\
\hline \multirow{2}{*}{$\begin{array}{l}\text { High business-related } \\
\text { experience }\end{array}$} & Male & 20 & 87.0 & 3 & 13.0 & 23 & 100.0 \\
\hline & Female & 7 & 77.8 & 2 & 22.2 & 9 & 100.0 \\
\hline Total & & 27 & 84.4 & 5 & 15.6 & 32 & 100.0 \\
\hline \multirow{2}{*}{$\begin{array}{l}\text { Low business-related } \\
\text { experience }\end{array}$} & Male & 3 & 23.1 & 10 & 76.9 & 13 & 100.0 \\
\hline & Female & 4 & 16.0 & 21 & 84.0 & 25 & 100.0 \\
\hline Total & & 7 & 18.4 & 31 & 81.6 & 38 & 100.0 \\
\hline Total Male & & 23 & 63.9 & 13 & 36.1 & 36 & 100.0 \\
\hline Total Female & & 11 & 32.4 & 23 & 67.6 & 34 & 100.0 \\
\hline Overall Total & & 34 & 48.6 & 36 & 51.4 & 70 & 100.0 \\
\hline
\end{tabular}

TABLE 2: Chi-square test.

\begin{tabular}{|c|c|c|c|c|c|}
\hline Experience & Value & $d f$ & $\begin{array}{c}\text { Asymptotic significance } \\
\text { (two-sided) }\end{array}$ & $\begin{array}{l}\text { Exact significance } \\
\text { (two-sided) }\end{array}$ & $\begin{array}{l}\text { Exact significance } \\
\text { (one-sided) }\end{array}$ \\
\hline \multicolumn{6}{|l|}{ High business-related experience } \\
\hline Pearson chi-square & $0.413^{\mathrm{a}}$ & 1 & 0.520 & & \\
\hline Continuity correction ${ }^{b}$ & 0.010 & 1 & 0.919 & & \\
\hline Likelihood ratio & 0.391 & 1 & 0.532 & & \\
\hline Fisher's exact test & & & & 0.604 & 0.437 \\
\hline Linear-by-linear association & 0.400 & 1 & 0.527 & & \\
\hline $\mathrm{N}$ of valid cases & 32 & & & & \\
\hline \multicolumn{6}{|l|}{ Low business-related experience } \\
\hline Pearson chi-square & $0.285^{c}$ & 1 & 0.593 & & \\
\hline Continuity correction ${ }^{\mathrm{b}}$ & 0.009 & 1 & 0.926 & & \\
\hline Likelihood ratio & 0.278 & 1 & 0.598 & & \\
\hline Fisher's exact test & & & & 0.672 & 0.451 \\
\hline Linear-by-linear association & 0.278 & 1 & 0.598 & & \\
\hline Total Pearson chi-square & $6.962^{\mathrm{d}}$ & 1 & 0.008 & & \\
\hline Total Continuity correction ${ }^{b}$ & 5.756 & 1 & 0.016 & & \\
\hline Total Likelihood ratio & 7.085 & 1 & 0.008 & & \\
\hline Total Fisher's exact test & & & & 0.010 & 0.008 \\
\hline Total Linear-by-linear association & 6.862 & 1 & 0.009 & & \\
\hline Total $N$ of valid cases & 70 & & & & \\
\hline
\end{tabular}

a, 0 cells $(0.0 \%)$ have expected count less than 5 . The minimum expected count is $11.69 ;{ }^{b}$, Computed only for a $2 \times 2$ table; ${ }^{c}, 0$ cells $(0.0 \%)$ have expected count less than 5 . The minimum expected count is $8.68 ;{ }^{\mathrm{d}}, 0$ cells $(0.0 \%)$ have expected count less than 5 . The minimum expected count is 13.60 . 
From the first partial table relating to high business-related experience, it can be noted that $87 \%$ of male and $77.8 \%$ of female respondents reported high firm performance. In the second partial table relating to low business-related experience, $76.9 \%$ of male and $84 \%$ of female entrepreneurs with low business-related experience indicated low or poor firm performance. From the partial table relating to high business experience, it can be concluded that firms of both male and female entrepreneurs with high business-related experience are more likely to be superior in terms of performance. However, looking closely at the partial table relating to low business-related experience, it can as well be concluded that firms for male and female business owners with low business-related experience are less likely to perform. Table 2 outlines the chi-square test results to determine whether a significant association can be found between gender and firm performance among SME owners with high/low business-related experience.

After controlling for business-related experience, the results displayed in Table 2 indicate that SME owners with high business-related experience obtained a chi-square value $=$ $0.413, d f=1$ and $p=0.52$ greater than $p=0.05$. This means that there is insufficient evidence against the null hypothesis which claims that no significant association can be found between gender and SME performance among SME owners with high business-related experience in the population from which the sample data was drawn. This article therefore fails to reject the null hypothesis $H 2$. With regard to SME owners with low business-related experience, a chi-square value $=0.285, d f=1$ and $p=0.593$ greater than $p=0.05$ was obtained. The results indicate that there is insufficient evidence against the null hypothesis claiming that no significant association can be found between gender and firm performance amongst SME owners with low businessrelated experience in the population from which the sample data were drawn. This article therefore fails to reject the null hypothesis H3. The above findings reveal that when controlling for the level of business-related experience between male-owned and female-owned SMEs, there is no difference in the performance of SMEs. The article disputes the findings by Watson (2002) who concluded that underperformance is not a function of experience or skills shortage or lack of competence in managing the firm but is directly attributable to unequal levels of starting capitalisation (finance). For example, a groundbreaking study by Mabaso (2008) conducted on SMEs established by retrenched Telkom workers, who were provided with finance to start businesses in South Africa, concluded that inadequate managerial experience and training were the major reasons for weak performance and failure of SMEs. This study, therefore, provides evidence in support of Mabaso (2008) that when SMEs are capitalised in the same manner in relation to business-related experience, no differences in performance are found in either male- or female-owned firms, considering that there is no change in behaviour of other performance-related factors.

\section{Implications}

To close the gender gap in SME performance in emerging economies, business incubators, often established at universities or business schools, are of particular value to female business owners in providing infrastructure, links to investors and market opportunities as well as personalised assistance and training. Therefore, it is clear that female SME owners, in particular, should utilise these institutions to enhance their chances of success and realise better firm performance and high business-related experience. Programmes engaging business-related experienced female business owners in providing advice to potential women business owners help enhance the performance of femaleowned SMEs. According to the Organisation for Economic Cooperation and Development (OECD 2012), there is a need for a policy to raise the awareness of entrepreneurship as a career option for women. Additionally, programmes are also needed to boost self-esteem and growth expectations among potential and established women business owners. Brush et al. (2011) emphasised that men have greater faith in their entrepreneurial experiences (high or low) and are also optimistic about the profitability of their enterprise. Female business owners' networks, which are major sources of managerial and technical expertise as well as opportunities for successful self-employment, can bolster the selfconfidence of women business owners and enhance their business-related experience and firm performance as well.

\section{Conclusion}

Contrary to evidence provided in literature, the study concludes that when focusing on the impact of gender on entrepreneurship with the aim of comparing business outcomes of male- and female-owned entities, while ignoring the role of key variables such as business-related experience, may yield misleading results. This study provides evidence indicating that when gender is factored in as the only independent variable, performance significantly differs between genders in support of extant literature. However, when other key factors such as managerial experience, prior business ownership and industry experience of entity owners are also taken into consideration, the findings of the study provide evidence to indicate that there is no significant difference in the performance of male- and female-owned entities. This also happens to be the major contribution of this study to literature.

\section{Limitations of the study}

The researchers of this study surveyed SMEs that had been in existence for more than 3 years. The major reason for considering firms above the age of 3 was to isolate fluctuations in firm performance. Thus, issues relating to age were not highly controlled. In other words, the average age of maleowned firms versus the average age of female-owned firms was ignored. There is a strong perception that older firms may be better off in terms of market share, suppliers and competent networks, which are crucial factors in determining the overall firm performance. 


\section{Acknowledgements}

\section{Conflict of interest}

The authors declare that they have no competing interests which may negatively affect their contribution to this article.

\section{Authors' contributions}

H.S. conceptualised the study, collected data, analysed the data, interpreted the results and did the majority of writing of the article. E.C.R. provided guidance on the design of the study and content of the literature.

\section{References}

Akinboade, O.A., 2015, 'Determinants of SMEs growth and performance in Cameroon's central and littoral provinces' manufacturing and retail sectors', African Journal of Economic and Management Studies 6(2), 183-196. http:// dx.doi.org/10.1108/AJEMS-03-2013-0033

Amin, M. \& Kushnir, K., 2012, 'Gender disparity in human capital: Going beyond schooling', Mimeograph, viewed 15 July 2014, from http://works.bepress.com/ mohammad amin/46/

Amobi, A.O., 2006, 'Entrepreneur human capital endowments and minority busines viability', Journal of Human Resources 20(4), 540-554.

Berger, N.A., Kirk, T. \& Schaeck, K., 2012, 'Executive board composition and bank risk taking', Journal of Corporate Finance 28, 48-65.

Billson, L., 2011, Contributions of women to family businesses as evidenced in the Eastern Cape, Masters dissertation, Unpublished, Nelson Mandela University, Port Elizabeth.

Boden, R., 1996, 'Gender and self-employment selection: An empirical assessment', Journal of Socio-Economics 25(6), 671-682. http://dx.doi.org/10.1016/S10535357(96)90046-3

Boden, R. \& Nucci, A. 2000, 'On the survival prospects of men's and women's new business ventures', Journal of Business Venturing 4, 347-362. http://dx.doi. org/10.1016/S0883-9026(98)00004-4

Bosma, N.S., Van Praag, C.M., Thurik, A.R. \& De Wit, G., 2004, 'The value of human and social capital investments for the business performance of startups', Small Business Economics 23, 227-236. http://dx.doi.org/10.1023/B:SBEJ. 0000032032.21192 .72

Botha, M., 2009, 'The Entrepreneur', in G. Nieman \& C. Nieuwenhuizen (eds.), Entrepreneurship: A South African perspective, 2 nd edn., Van Schaik, Pretoria, pp. 29-51.

Brush, C.G., Greene, P.G., Kelley, D.J. \& Litovsky, Y., 2011, 2010 women's report, global entrepreneurship monitor executive report, Babson College, Wellesley, MA.

Calas, M. \& Smircich, L., 1989, 'Using the F word: Feminist theory and the social consequences of organisational research', paper presented at the Annual Meeting of the Academy of Management, Washington, DC, Aug 1, 1989, pp. 355-359.

Carton, R.B. \& Hofer, C.W. 2006, Measuring organisation performance-Metrics for entrepreneurship and strategic management research, Edward Elgar, Cheltenham.

Chinomona, E. \& Maziriri, E.T., 2015, 'Women in action: Challenges facing women entrepreneurs in the Gauteng Province of South Africa', International Business \& Economics Research Journal 14(6), 835-850. http://dx.doi.org/10.19030/iber. v14i6.9487

Cliff, J.E., 1998, 'Does one size fit all? Exploring the relationship between attitudes to growth, gender and business size', Journal of Business Venturing 13, 523-542. http://dx.doi.org/10.1016/S0883-9026(97)00071-2

Coleman, S., 2002, 'Sources of small business capital: A comparison of men- and women-owned small businesses', Journal of Applied management and Entrepreneurship 4(2), 138-152.

Cooper, A.C., Gimeno-Gascon, J.F. \& Woo, C., 1994, 'Initial human and financial capital as predictors of new venture performance', Journal of Business Venturing 9(5), 371-395. http://dx.doi.org/10.1016/0883-9026(94)90013-2

De Tienne, D.R. \& Chandler, G.N., 2007, 'The role of gender in opportunity identification', Entrepreneurship, Theory and Practice 31(3), 365-386. http://dx. doi.org/10.1111/j.1540-6520.2007.00178.x

Delmar, F. \& Wiklund, J., 2008, 'The effect of small business managers' growth motivation on firm growth: A longitudinal study', Entrepreneurship Theory and Practice 32(3), 437-453. http://dx.doi.org/10.1111/j.1540-6520.2008.00235.x

Dyke, L.S., Fischer, E.M. \& Reuber, A.R., 1992, 'An inter-industry examination of the impact of owner experience on firm performance', Journal of Small Business Management 30, 72-87.

Eikhof, D.R., 2012, 'A double-edged sword: 21st century workplace trends and gender equality', Gender in Management 27(1), 7-22. http://dx.doi.org/10.1108/ 17542411211199246

Eikhof, D.R., Summers, J. \& Carter, S., 2013, 'Women doing their own thing: Media representations of female entrepreneurship', International Journal of Entrepreneurial Behaviour \& Research 19(5), 547-564. http://dx.doi.org/10.1108/ IJEBR-09-2011-0107
Elizabeth, C. \& Baines, S., 1998, 'Does gender affect business performance? A study of micro-businesses in business service in the UK', Entrepreneurship and Regiona Development: An International Journal 10(2), 117-135. http://dx.doi. Development: An International

Fairlie, R.W. \& Robb, M., 2008, Race and entrepreneurial success: Black, Asian- and White-owned businesses in the United States, MIT Press, Cambridge.

Fapohunda, T.M., 2013, 'Gender differences in human capital and personality traits as drivers of gender gap in entrepreneurship: Evidence from Nigeria', British Journa of Economics Management and Trade 3(1), 30-47. http://dx.doi.org/10.9734/ BJEMT/2013/2470

Fatoki, O., 2011, 'The impact of human, social and financial capital on the performance of small and medium-sized enterprises (SMEs) in South Africa', Journal of Social Science 29(3), 193-204.

Fatoki, O., 2012, 'The influence of entrepreneurial orientation on access to debt finance and firm performance of small and medium enterprises in South Africa', Journal of Social Sciences 32(2), 121-131.

Fatoki, O. \& Asah, F., 2011, 'The impact of firm and entrepreneurial characteristics on access to debt finance by SMEs in King Williams' Town, South Africa', Internationa Journal of Business and Management 6(8), 170. http://dx.doi.org/10.5539/ijbm. v6n8p170

Fischer, E.M., Reuber, A.R. \& Dyke, L.S. 1993, 'A theoretical overview and extension of research on sex, gender and entrepreneurship', Journal of Business Venturing 8 , research on sex, gender and entrepreneurship', Journal of Bus
151-168. http://dx.doi.org/10.1016/0883-9026(93)90017-Y

Gatewood, E.J., Brush, C.G., Carter, N.M., Greene, P.G. \& Hart, M.M., 2009, 'Diana: A symbol of women entrepreneurs' hunt of knowledge, money and the rewards of entrepreneurship', Small Business Economics 32, 129-144. http://dx.doi. org $/ 10.1007 / \mathrm{s} 11187-008-9152-8$

Goffee, R. \& Scase, R., 1985, Women in charge, Allen \& Urwin, London.

Gottschalk, S. \& Niefert, M. 2012, 'Gender differences in business success of German start-up firm', International Journal of Entrepreneurship and Small Business Management 18(1), 15-46. http://dx.doi.org/10.1504/IJESB.2013.050750

Headd, B., 2003, 'Redefining business success: Distinguishing between closure and failure', Small Business Economics 21(1), 51-61. http://dx.doi.org/10.1023/ A: 1024433630958

Hundley, G., 2001, 'Why women earn less in self-employment', Journal of Labour Research 22(4), 817-829. http://dx.doi.org/10.1007/s12122-001-1054-3

Kalleberg, A. \& Leicht, K., 1991, 'Gender and organisational performance: Determinants of small business survival and success', Academy of Management Journal 34(1), 136-161. http://dx.doi.org/10.2307/256305

Keeley, R.H. \& Roure, J.B., 1990, 'Management strategy and industry structure as influences on the success of new firms: A structural model', Journal of Management Sciences 36(10), 1256-1267. http://dx.doi.org/10.1287/mnsc.36. 10.1256

Klapper, L.F. \& Parker, S.C., 2011, 'Gender and the business environment for new firm creation', World Bank Research Observer 26(2), 237-257. http://dx.doi. org/10.1093/wbro/lkp032

Loscocco, K.A., Robinson, J., Hall, R.H. \& Allen, J.K., 1991, 'Gender and small business success: An inquiry into women's relative disadvantage', Social Forces $70(1)$ 65-85. http://dx.doi.org/10.1093/sf/70.1.65

Mabaso, N.R., 2008, 'An investigation into small business failures with specific reference to retrenched Telkom employees in the far west rand (Mogale City, Randfontein and Soweto)', Masters dissertation, Unpublished, University of South Africa, Pretoria.

Mba, N., 2006, 'Women and politics in colonial Nigeria', paper presented at the Symposium on the Impact of Colonialism on Women in Nigeria Women's Research Documentation Centre, Institute of African Studies, University of Ibadan, 16-18th October.

Menzies, T.V., Diochon, M. \& Gasse, Y., 2004, 'Examining venture-related myths concerning women entrepreneurs', Journal of Developmental Entrepreneurship 9 , 89-107.

Myers, M.D., 2009, Qualitative research in business and management, Sage, London.

Naudé, W. (ed.), 2013, 'Entrepreneurship and economic development theory evidence and policy', IZA Discussion Paper Number 7507, in Entrepreneurship and economic development, p. 304, Palgrave Macmillan, New York.

Omiunu, O.G., 2014, 'Investigating the challenges faced by women rice farmers in Nigeria', Open Access Library Journal 1, e503. http://dx.doi.org/10.4236/ oalib.1100503

Organisation for Economic Cooperation and Development (OECD), 2012, Closing the gender gap: Act now, OECD Publishing, Paris. http://dx.doi.org/10.1787/ 97892264179370

Popescu, A.L., Deaconu, A. \& Popescu, T., 2014, 'The impact of gender difference at Romanian small and medium enterprises (SMEs) management level, analysed by organisational citizenship behaviour (OCB) lens', Procedia Economics and Finance 8, 563-569. http://dx.doi.org/10.1016/S2212-5671(14)00129-4

Powell, G.N., Kimberly, A. \& Eddleston, A., 2008, 'The paradox of the contented female business owner', Journal of Vocational Behaviour 73, 24-36. http://dx.doi. org/10.1016/j.jvb.2007.12.005

Richbell, S., Watts, H. \& Wardle, P., 2006, 'Owner-managers and business planning in the small firm', International Small Business Journal 24(5), 496-514. http://dx.doi. org/10.1177/0266242606067275

Robb, A., 2000, 'The role of race, gender and discrimination in business survival', Doctoral dissertation, University of Michigan Press, Ann Arbor, MI.

Robb, A., 2002, 'Entrepreneurial performance by women and minorities: The case of new firms', Journal of Developmental Entrepreneurship 7(4), 383-397. 
Robb, A., 2008, 'An investigation of new firm performance by owner race, ethnicity, and gender', Working paper, 2008 International Council for Small Business World Conference, viewed 6 May 2014, from http://sbaer.uca.edu/research/sbi/2008/ chalo3f.html

Robb, A. \& Wolken, J., 2002, Firm, owner, and financing characteristics: Differences between female and male owned small businesses, Federal Reserve working paper series: 2002-18, Federal Reserve, Washington DC.

Robb, A.M. \& Watson, J., 2012, 'Gender differences in firm performance: Evidence from new ventures in the United States', Journal of Business Venturing 27, 544-558.

Rosa, P., Carter, S. \& Hamilton, D., 1996, 'Gender as a determinant of small business performance: Insights from a British study', Small Business Economics 8, 463-478.

Schwab, D.P., 2013, Research methods for organisational studies, 2nd edn., viewed 21 May 2014, from http://books.google.co.za/books?id=CYeRUzj2A_MC\&pg=PA47\& $\mathrm{dq}=$ questionnaire+pilot+testing\&hl=en\&sa=X\&ei=IIEUUvPaK4qV̄hQfk04D4CQ\& $r$ edir_esc=y\#v=onepage\&q=questionnaire $\% 20$ pilot $\% 20$ testing\& $f=$ false

Shava, H. \& Rungani, E.C., 2014, 'Gender differences in business related experience amongst SME owners in King Williams Town, South Africa: A comparative analysis', Mediterranean Journal of Social Sciences 5(20), 2687-2697.

Singh, R., 2012, 'Women entrepreneurship issues, challenges and empowerment through self-help groups: An overview of Himachal Pradesh', International Journal of Democratic and Development Studies 1(1), 5-58.
Soriano, D.R. \& Castrogiovanni, G.J., 2012, 'The impact of education, experience and inner circle advisors on SME performance: Insights from a study of public development centers', Small Business Economics 38(3), 333-349.

Srinivisan, R., Woo, C. \& Cooper, A., 1994, Performance determinants for male and female entrepreneurs, Working paper 1053, Purdue University, West Layafette, IN

Terjesen, S. \& Hessels, J., 2016, 'Comparative international entrepreneurship: A review and research agenda', Journal of Management 42(1), 299-344.

Vadnjal, J. \& Zupan, B., 2009, 'The role of women in family businesses', Economic and Business Review 11(2), 159-177.

Van De Ven, A., Hudson, R. \& Schroeder, D.M., 1984, 'Designing new business startups: Entrepreneurial, organisational, and ecological considerations', Journal of Management 10(1), 87-107.

Verheul, I., Thurik, R. \& Grilo, I., 2008, Explaining preferences and actual involvement in self-employment: New insights into the role of gender, Research Paper ERS2008-003-ORG Revision, Erasmus Research Institute of Management, Rotterdam.

Watson, J., 2002, 'Comparing the performance of male and female controlled businesses: Relating outputs to inputs', Entrepreneurship, Theory and Practice 26(3), 91-100

Wiid, J. \& Diggines, C., 2015, Marketing research, 3rd edn., Juta, Cape Town.

Zikmund, W.G. \& Babin, B.J., 2009, Essentials of marketing research, 4th edn., Cengage Learning, Boston, MA. 